\title{
Multi-trait and repeatability models for genetic evaluation of litter traits in pigs considering different farrowings
}

\author{
Modelos multicaracterísticos e de repetibilidade para avaliação genética de \\ características de leitegada em suínos considerando diferentes partos
}

\author{
COSTA, Edson Vinícius ${ }^{1,2}$; VENTURA, Henrique Torres ${ }^{2}$; FIGUEIREDO, Elsio \\ Antônio Pereira $^{3}$; SILVA, Fabyano Fonseca e ${ }^{1}$; GLÓRIA, Leonardo Siqueira ${ }^{1}$; \\ GODINHO, Rodrigo Mezêncio ${ }^{1}$; RESENDE, Marcos Deon Vilela de ${ }^{4}$; LOPES Paulo \\ Sávio $^{1 *}$
}

\author{
${ }^{1}$ Universidade Federal de Viçosa, Departamento de Zootecnia, Viçosa, Minas Gerais, Brasil. \\ ${ }^{2}$ Associação Brasileira dos Criadores de Zebu, Uberaba, Minas Gerais, Brasil \\ ${ }^{3}$ Embrapa Suínos e Aves, Concórdia, Santa Catarina, Brasil. \\ ${ }^{4}$ Embrapa Florestas, Colombo, Paraná, Brasil. \\ *Endereço para correspondência: plopes@ufv.br
}

\section{SUMMARY}

We aimed to compare multi-trait and repeatability models to estimate genetic parameters for the traits number of piglets born alive (NBA) and alive at 3 week of age (NP3), litter weight at birth (LW0) and at 3 week of age (LW3), and mean piglet weight at birth (MW0) and at 3 week of age (MW3), considering the first three farrowings of Landrace sows. Heritability $\left(\mathrm{h}^{2}\right)$ estimates showed an increasing pattern up to the third farrowing for LW0 and MW3. For NBA, NP3, LW3, and MW0 $\mathrm{h}^{2}$ increased from the first to the second and decreased from the second to the third farrowing. In general, heritability estimated in the repeatability model was lower than the mean of the estimates in the multi-trait model. The traits LWO, MW0, and MW3 presented high genetic correlation among different farrowings (0.9610.997), while NBA, NP3, and LW3 (0.092-0.986) presented irregular values among farrowings. The corrected Akaike information criterion shows that the repeatability model is not indicated for almost all of the studied traits. These results indicate that the multi-trait model is recommended for genetic evaluation of the traits number of piglets born alive and alive at 3 week of age, litter weight and mean piglet weight at birth and 3 week of age, in different farrowings, as different traits.

Keywords: genetic parameter, parity, reproductive traits, REML

\section{RESUMO}

Objetivou-se comparar os modelos multicaracterístico e de repetibilidade na estimação de parâmetros genéticos para as características número de leitões nascidos vivos (NLN) e às três semanas de idade (NL3), peso da leitegada ao nascimento (PLN) e às três semanas de idade (PL3), e peso médio do leitão ao nascimento (PMLN) e às três semanas de idade (PML3), considerando os três primeiros partos de fêmeas da raça Landrace. As estimativas de herdabilidade $\left(\mathrm{h}^{2}\right)$ aumentaram até a terceira ordem de parto para as características PLN e PML3. Para NLN, NL3, PL3 e PMLN as $\mathrm{h}^{2}$ aumentaram da primeira para a segunda parição e reduziram da segunda para terceira parição. Em geral, as herdabilidades estimadas via modelo de repetibilidade foram menores que a média das estimativas obtidas utilizando o modelo muticaracterístico. As características PLN, PMLN e PML3 apresentaram altas correlações genéticas entre as diferentes parições $(0,961$ $0,997)$, enquanto as características NLN, NL3 e PL3 (0,092-0,986) apresentaram valores irregulares de correlações genéticas entre as parições. Pelo critério de informação de Akaike corrigido o modelo de repetibilidade não foi indicado para a maioria das características estudadas. Esses resultados indicam que 0 modelo multicaracterístico é recomendado para 
avaliação genética das características número de leitões nascidos vivos e às três semanas de idade, peso da leitegada ao nascimento e às três semanas de idade e peso médio do leitão ao nascimento e às três semanas de idade, em diferentes parições, como características diferentes.

Palavras-chave: parâmetro genético, características reprodutivas, parição, REML

\section{INTRODUCTION}

The success of pig breeding programs depends on the appropriate models for genetic evaluation of sows by verifying the presence of genetic association between different litter traits as well as the presence of such associations within the farrowing order. The repeatability model assumes that litter traits in different farrowings are characterized as repeated measures of the same trait (PILES et al., 2006). Many pig breeding programs still use this model, although the genetic basis for these traits may differ in each farrowing. In contrast, the multi-trait model treats different farrowings as different traits. Although Noguera et al. (2002) and Krupa and Wolf (2013) carried out analysis of litter size for multiple parities with production traits in pigs, there are no studies comparing both multi-trait and repeatability models for genetic evaluation including many litter traits collected in different order of farrowings.

Many litter traits have economic impact in the pork production system and an equilibrium between traits is crucial to improve sows' productivity (FOXCROFT et al., 2010). The main components of the trait litter size are sow ovulation rate, early embryonic and fetal survival until farrowing, and survival of piglets from birth until weaning (LUND et al., 2002). Putz et al. (2015) suggested that the number weaned could possibly be used as an effective litter trait; and Sorensen et al. (2000) reported that another important trait is litter weight, since it is the main factor for piglet survival and has a negative correlation with litter size.

There is a lack of research comparing the estimation of accurate breeding values of repeated measures analyzed as single or multi-trait models, i.e., accounting for correlations between the orders of farrowings. Such issues are important to reveal how a given trait measured continuously along the life of the same animal should be analyzed. Thus, toward this orientation, the aim of this study was to compare the multi-trait and repeatability models on the genetic evaluation of litter traits in Landrace pig population for different farrowings.

\section{MATERIAL AND METHODS}

The data used in the present study originated from Landrace pigs produced by a farm located in the state of Santa Catarina, southern Brazil. The following traits at first, second, and third farrowings were considered: number of piglets born alive (NBA) and alive at 3 week of age (NP3), litter weight at birth (LW0) and at 3 week of age (LW3), and mean piglet weight at birth (MW0) and at 3 week of age (MW3). Number of records, means and coefficients of variation of traits in different farrowings are presented in Table 1.

The analyses were carried out, considering each trait among farrowings, using two different statistical models: multi-trait and repeatability. These models were fitted using the Wombat software (MEYER, 2007). 
Rev. Bras. Saúde Prod. Anim., Salvador, v.17, n.4, p.666-676 out./dez., 2016 http://www.rbspa.ufba.br ISSN 15199940

Two models were used to estimate genetic parameters:

$\mathrm{y}=\mathrm{Xb}+\mathrm{Z}_{1} \mathrm{a}+\mathrm{e} \quad$ (multi-trait)

$\mathrm{y}=\mathrm{Xb}+\mathrm{Z}_{1} \mathrm{a}+\mathrm{Z}_{2} \mathrm{p}+\mathrm{e}$

(repeteability)

where $y$ is the vector of observations; $b$ is the vector of fixed effects of contemporary group of year-season; $a$ is the vector of additive genetic effects (breeding values); $p$ is the vector of random effect of permanent environmental; and $e$ is the vector of random residuals. $\mathrm{X}, \mathrm{Z}_{1}$ and $\mathrm{Z}_{2}$ are incidence matrices.

Table 1. Number of records $(\mathrm{N})$, mean and coefficient of variation $(\mathrm{CV})$

\begin{tabular}{lccccccccc}
\hline Farrowing & \multicolumn{3}{c}{ First } & \multicolumn{3}{c}{ Second } & \multicolumn{3}{c}{ Third } \\
\hline & $\mathrm{N}$ & Mean & $\mathrm{CV}(\%)$ & $\mathrm{N}$ & Mean & $\mathrm{CV}(\%)$ & $\mathrm{N}$ & Mean & $\mathrm{CV}(\%)$ \\
\hline NBA & 565 & 10.59 & 23.11 & 429 & 10.69 & 26.25 & 351 & 11.24 & 23.65 \\
NP3 & 568 & 9.67 & 25.72 & 418 & 10.00 & 26.75 & 343 & 10.53 & 24.94 \\
LW0 & 537 & 14.41 & 40.93 & 428 & 16.24 & 41.84 & 351 & 17.09 & 54.96 \\
LW3 & 515 & 59.45 & 30.32 & 391 & 67.39 & 29.15 & 321 & 69.65 & 28.70 \\
MW0 & 572 & 1.38 & 35.98 & 428 & 1.56 & 43.98 & 351 & 1.54 & 45.49 \\
MW3 & 511 & 6.18 & 16.68 & 382 & 6.71 & 17.20 & 314 & 6.65 & 16.66 \\
\hline
\end{tabular}

$\mathrm{NBA}=$ number of piglets born alive; NP3 = number of piglets alive at 3 week of age; LW0 $=$ litter weight at birth; LW3 = litter weight at 3 week of age; MW0 = mean pglet weight at birth; MW3 = mean piglet weight at 3 week of age.

For the multi-trait model, it was assumed $\mathrm{a} \sim \mathrm{N}\left(0, \mathrm{~A} \otimes G_{0}\right)$, being $\mathrm{A}$ is the additive relationship matrix among the animals and $G_{0}$ is the additive genetic variance-covariance matrix for each trait among farrowings, $\mathrm{G}_{0}=$

$$
\left[\begin{array}{ccc}
\sigma_{\mathrm{a} 1}^{2} & \sigma_{\mathrm{a} 1, \mathrm{a} 2} & \sigma_{\mathrm{a} 1, \mathrm{a} 3} \\
\sigma_{\mathrm{a} 2, \mathrm{a} 1} & \sigma_{\mathrm{a} 2}^{2} & \sigma_{\mathrm{a} 2, \mathrm{a} 3} \\
\sigma_{\mathrm{a} 3, \mathrm{a} 1} & \sigma_{\mathrm{a} 3, \mathrm{a} 2} & \sigma_{\mathrm{a} 3}^{2}
\end{array}\right]
$$

and $\otimes$, Kronecker product operator and $\mathrm{e} \sim \mathrm{N}\left(0, \mathrm{I} \otimes \mathrm{R}_{0}\right)$, where $\mathrm{I}$ and $\mathrm{R}_{0}$ are, respectively, an identity and residual variance-covariance matrix for each trait among farrowings, $\mathrm{R}_{0}=$

$$
\left[\begin{array}{ccc}
\sigma_{\mathrm{e} 1}^{2} & \sigma_{\mathrm{e} 1, \mathrm{e} 2} & \sigma_{\mathrm{e} 1, \mathrm{e} 3} \\
\sigma_{\mathrm{e} 2, \mathrm{e} 1} & \sigma_{\mathrm{e} 2}^{2} & \sigma_{\mathrm{e} 2, \mathrm{e} 3} \\
\sigma_{\mathrm{e} 3, \mathrm{e} 1} & \sigma_{\mathrm{e} 3, \mathrm{e} 2} & \sigma_{\mathrm{e} 3}^{2}
\end{array}\right] .
$$

For repeatability, we assumed $\mathrm{a} \sim \mathrm{N}\left(0, A \sigma_{\mathrm{a}}^{2}\right)$ where $A$ is the additive relationship matrix among the animals and $\sigma_{\mathrm{a}}^{2}$ is the additive genetic variance, $\quad p \sim N\left(0, I \sigma_{p}^{2}\right)$, being $I$ is identity matrix and $\sigma_{\mathrm{p}}^{2}$ is the permanent environmental variance, and $\mathrm{e} \sim \mathrm{N}\left(0, \mathrm{I} \sigma_{\mathrm{e}}^{2}\right)$, being $\mathrm{I}$ is identity matrix and $\sigma_{\mathrm{e}}^{2}$ is the residual variance.

We built an index with equal weights considering predicted breeding values for all traits from the multi-trait model in order to obtain an index value for each sow. The percentages of common selected individuals were obtained for increasing levels based on predicted breeding values and index values when using, respectively, the repeatability and multi-trait models.

The models were compared by the corrected Akaike criterion, AICc, (AKAIKE, 1974; SUGIURA, 1978). In order to facilitate the interpretation of the AICc values in terms of the superiority of one model over another, the likelihood probabilities $\left(\mathrm{W}_{\mathrm{i}}\right)$ were 
Rev. Bras. Saúde Prod. Anim., Salvador, v.17, n.4, p.666-676 out./dez., 2016 http://www.rbspa.ufba.br ISSN 15199940

calculated (BURNHAM and ANDERSON, 2004) as follows: $W_{i}=\frac{\exp \left(-\Delta_{i} / 2\right)}{\sum_{r=1}^{R} \exp \left(-\Delta_{r} / 2\right)}$, where $\Delta_{\mathrm{i}}$ is the difference between $\mathrm{AIC}_{\mathrm{c}}$ values, $\left(\Delta_{\mathrm{i}}=\right.$ $\left.\mathrm{AIC}_{\mathrm{i}}-\mathrm{AIC}_{\text {min }}\right)$, in which $\mathrm{AIC}_{\text {min }}$ represents the minimum AICc. The $W_{i}$ represents the probability (varying from zero to one) of a given model $i$ be the best one inside the set of compared models. Thus, models with higher $\mathrm{W}_{\mathrm{i}}$ values should be preferred.

\section{RESULTS}

Here we compared the heritability, additive genetic and phenotypic variances obtained using the multi-trait model versus those obtained with the repeatability model. Estimations of genetic and phenotypic correlation components were fitted for the multitrait model and repeatability coefficient estimations for the repeatability model. The traits analyzed were the number of piglets born alive (NBA) and alive at 3 week of age (NP3), litter weight at birth (LW0) and at 3 week of age (LW3), and mean piglet weight at birth (MW0) and at 3 week of age (MW3), considering the first three farrowings.

The trait NBA presented lower value for additive genetic variance at first farrowing in the multi-trait model (Table 2). Estimated heritability for this trait at first farrowing was also lower than for the other farrowings (Table 3). Additive genetic and phenotypic covariances obtained for NBA between the first and the third farrowings presented lower values when compared to the other covariances. Furthermore, the value of those variances increased from the first to the second farrowing and decreased from the second to the third farrowing (Table 2).

Table 2. Estimates of additive genetic variance (diagonal), additive genetic covariance (below diagonal), and phenotypic covariance (above diagonal) fit with the multi-trait model considering the first three farrowings

\begin{tabular}{|c|c|c|c|c|c|c|c|}
\hline Farrowing & & 1 & 2 & 3 & 1 & 2 & 3 \\
\hline & & \multicolumn{3}{|c|}{ NBA } & \multicolumn{3}{|c|}{ NP3 } \\
\hline & 1 & 0.2837 & 1.4043 & 0.9273 & 0.2508 & 1.0822 & 0.8417 \\
\hline & 2 & 0.4302 & 0.9076 & 1.7572 & 0.3193 & 0.8216 & 1.4278 \\
\hline & 3 & 0.2816 & 0.2942 & 0.4492 & 0.0374 & 0.4147 & 0.6543 \\
\hline & & \multicolumn{3}{|c|}{ LW0 } & \multicolumn{3}{|c|}{ LW3 } \\
\hline & 1 & 0.1984 & 2.0937 & 2.2288 & 9.4201 & 54.7800 & 67.2350 \\
\hline & 2 & 0.4388 & 1.0227 & 4.1594 & 15.1970 & 44.6510 & 68.0750 \\
\hline & 3 & 0.7629 & 1.7266 & 3.0105 & 14.4600 & 40.6080 & 38.0110 \\
\hline & & \multicolumn{3}{|c|}{ MW0 } & \multicolumn{3}{|c|}{ MW3 } \\
\hline & 1 & 0.0097 & 0.0207 & 0.0177 & 0.0362 & 0.1617 & 0.1901 \\
\hline & 2 & 0.0159 & 0.0272 & 0.0218 & 0.0458 & 0.0627 & -0.0261 \\
\hline & 3 & 0.0125 & 0.0214 & 0.0169 & 0.0594 & 0.0772 & 0.1016 \\
\hline
\end{tabular}

$\mathrm{NBA}=$ number of piglets born alive; NP3 $=$ number of piglets alive at 3 week of age; LW0 $=$ litter weight at birth; LW3 = litter weight at 3 week of age; MW0 = mean piglet weight at birth; MW3 = mean piglet weight at 3 week of age. 
Rev. Bras. Saúde Prod. Anim., Salvador, v.17, n.4, p.666-676 out./dez., 2016 http://www.rbspa.ufba.br ISSN 15199940

The same pattern was observed for heritability estimates using the multitrait model. Genetic correlation for the NBA trait was higher in the two first farrowings and of a lesser magnitude between the second and third farrowings (Table 3). Estimated heritability using the repeatability model revealed values closer to those obtained when the multi-trait model was used for the three farrowings (Table 3 and Table 4).

The patterns described above for NBA were also observed when NP3 was considered using the multi-trait model. Thus, we observed increases in additive genetic variance and in heritability from the first to the second farrowing, as well as a decrease of these parameters from the second to the third farrowing (Table 2 and Table 3 ).

Table 3. Estimates of heritability (diagonal), genetic correlation (below diagonal), and phenotypic (above diagonal) fit with the multi-trait model considering the first three farrowings

\begin{tabular}{|c|c|c|c|c|c|c|}
\hline Farrowing & 1 & 2 & 3 & 1 & 2 & 3 \\
\hline & \multicolumn{3}{|c|}{ NBA } & \multicolumn{3}{|c|}{ NP3 } \\
\hline 1 & 0.0471 & 0.2034 & 0.1436 & 0.0422 & 0.1532 & 0.1310 \\
\hline 2 & 0.8478 & 0.1146 & 0.2373 & 0.7033 & 0.1194 & 0.2281 \\
\hline 3 & 0.7889 & 0.4608 & 0.0649 & 0.0923 & 0.5656 & 0.0964 \\
\hline & \multicolumn{3}{|c|}{ LW0 } & \multicolumn{3}{|c|}{ LW3 } \\
\hline 1 & 0.0203 & 0.1771 & 0.1879 & 0.0295 & 0.1555 & 0.1928 \\
\hline 2 & 0.9743 & 0.0714 & 0.2894 & 0.7410 & 0.1151 & 0.1772 \\
\hline 3 & 0.9872 & 0.9840 & 0.2088 & 0.7648 & 0.9857 & 0.1000 \\
\hline & \multicolumn{3}{|c|}{ MW0 } & \multicolumn{3}{|c|}{ MW3 } \\
\hline 1 & 0.2074 & 0.4132 & 0.3792 & 0.0447 & 0.2075 & 0.1842 \\
\hline 2 & 0.9843 & 0.5024 & 0.4314 & 0.9610 & 0.0752 & 0.1198 \\
\hline 3 & 0.9809 & 0.9970 & 0.3590 & 0.9800 & 0.9671 & 0.1285 \\
\hline
\end{tabular}

$\mathrm{NBA}=$ number of piglets born alive; NP3 $=$ number of piglets alive at 3 week of age; LW0 $=$ litter weight at birth; LW3 = litter weight at 3 week of age; MW0 = mean piglet weight at birth; MW3 = mean piglet weight at 3 week of age.

Table 4. Estimates of variance components, heritability, and repeatability coefficient fit with the repeatability model for number of piglets born alive (NBA), number of piglets alive at 3 week of age (NP3), litter weight at birth (LW0), litter weight at 3 week of age (LW3), mean piglet weight at birth (MW0) and mean piglet weight at 3 week of age (MW3)

\begin{tabular}{ccccccc}
\hline & NBA & NP3 & LWO & LW3 & MWO & MW3 \\
\hline$\sigma^{2}{ }_{\mathrm{a}}$ & 0.4887 & 0.3504 & 1.4772 & 22.4950 & 0.0046 & 0.0596 \\
$\sigma_{\mathrm{p}}^{2}$ & 0.8311 & 0.7697 & 0.2656 & 27.2360 & 0.0037 & 0.0539 \\
$\sigma_{\mathrm{e}}^{2}$ & 5.6505 & 5.7403 & 41.0840 & 332.6500 & 0.0480 & 1.0859 \\
$\mathrm{~h}^{2}$ & 0.0701 & 0.0511 & 0.0345 & 0.0588 & 0.0874 & 0.0496 \\
$\mathrm{r}$ & 0.1893 & 0.1633 & 0.0407 & 0.1301 & 0.1527 & 0.0949 \\
\hline
\end{tabular}

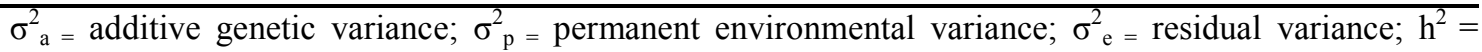
heritability; $r=$ repeatability coefficient. 
Estimated genetic correlations for NP3 between the first and the third farrowings were lower than the correlations obtained between this trait for the other farrowings (Table 3). The mean of additive genetic variance, and the mean of heritability for NP3 fitted with the multi-trait model were 0.5756 and 0.0860 , respectively. Comparing the additive genetic variance estimations for NP3 in the repeatability model versus the mean of multi-trait model for the different farrowings revealed underestimation of this variance fit with the repeatability model (Table 4). Heritability observed in the repeatability model was lower than the mean of estimates in the different farrowings of the multi-trait model (0.0511 and 0.0860, respectively) (Table 3 and Table 4 ). Permanent environmental effect $\left(p=r-h^{2}\right)$ was highly pronounced for the traits NP3 and NBA (Table 4).

Estimated heritability for LW0 using the repeatability model was higher than the heritability obtained using the multi-trait model, in the first farrowing. However, it was lower than the values obtained in the second and the third farrowings. The trait LW0 showed a rise in additive genetic variance estimates with increase in order of farrowing, in contrast to the estimates observed for the traits NBA and NP3. Estimations of genetic correlations for this trait were high but different from unity, with the highest value between the first and the third and the lowest between the first and the second farrowings. Mean of additive genetic variance in the multitrait model was 1.4105 . This value was lower than that fitted by the repeatability model.

For the LW3 trait, the increase in the order of farrowing showed an uneven additive genetic variance. The first farrowing corresponded to $21.1 \%$ and $24.8 \%$ of the variance obtained for the second and third farrowings, respectively. The trait LW3 also presented high genetic correlation between the farrowings, with the second and the third farrowings presenting the highest value for this parameter (Table 3). The mean of the heritabilities fitted by the multi-trait model was 0.0815 , a higher value than that fitted by the repeatability model. The value of permanent environmental variance for LW3 was the highest among all the traits analyzed herein. There was an underestimation of additive genetic variance in the repeatability model when compared to the mean of estimates obtained in the multi-trait model (30.6940).

The highest heritability and genetic correlations obtained in this study were fitted for the trait MW0. This trait followed the same pattern observed for NBA, NP3, and LW3 in additive genetic variance. The lowest additive genetic variance was observed on the first farrowing. The mean of the additive genetic variances obtained by the multitrait model for the three farrowings was 0.0179 . This mean was underestimated when compared with the variance obtained with the repeatability model. However, the mean of heritability in the multi-trait model (0.3562) was higher than heritability found with the repeatability model (Table 4 ).

The heritability estimated by the repeatability model was similar to that fitted with the multi-trait model for the trait MW3, at the first farrowing. However, this value was lower than the mean of the heritabilities for the three farrowings $(0.0828)$. The additive genetic variance was underestimated by the repeatability model. Large values for the genetic correlations were also observed for this trait. The heritabilities fitted by this model rose with the increase in the order of farrowing, as observed for LW0 (Table 3).

Table 5 presents the percentage of coincident selected animals, in increasing 
Rev. Bras. Saúde Prod. Anim., Salvador, v.17, n.4, p.666-676 out./dez., 2016 http://www.rbspa.ufba.br ISSN 15199940

percentile, fit with both models for all the litter traits analyzed herein. The values obtained varied considerably and, as expected, $100 \%$ coincidence was not observed at all.

The multi-trait model presented less values of corrected Akaike information criterion $(A I C C)$ than the repeatability model for all traits, except for LW3 (Table 6). For this reason, the likelihood probabilities (W) show that the repeatability model is the poorer choice for almost all of the studied traits, except for LW3.

Table 5. Percentage of coincident selected animals, in increasing percentile, fit with both the multi-trait and the repeatability models for litter traits

\begin{tabular}{lccc}
\hline \multicolumn{3}{c}{ Percentage of selected animals } \\
\hline Traits & $10 \%$ & $20 \%$ & $50 \%$ \\
\hline NBA & 87.01 & 91.94 & 84.74 \\
NP3 & 89.58 & 86.92 & 86.39 \\
LW0 & 79.23 & 82.33 & 75.11 \\
LW3 & 72.05 & 69.92 & 70.33 \\
MW0 & 88.72 & 93.12 & 82.40 \\
MW3 & 83.01 & 80.92 & 81.17 \\
\hline
\end{tabular}

NBA $=$ number of piglets born alive; NP3 = number of piglets alive at 3 week of age; LW0 = litter weight at birth; LW3 = litter weight at 3 week of age; MW0 = mean piglet weight at birth and MW3 = mean piglet weight at 3 week of age.

Table 6. Corrected Akaike information criterion $(A I C)$, difference among the AICc values $(\Delta)$, and likelihood probabilities $\left(W_{i}\right)$, for the multi-trait and repeatability models

\begin{tabular}{|c|c|c|c|}
\hline \multirow{2}{*}{ Trait } & \multicolumn{3}{|c|}{ Comparison criteria } \\
\hline & $A I C C$ & $\Delta$ & $W_{i}$ \\
\hline \multicolumn{4}{|l|}{$\mathrm{NBA}$} \\
\hline Multi-trait model & 3871.88 & 0.00 & $\approx 1.00$ \\
\hline Repeatability model & 3896.67 & 24.79 & $\approx 0.00$ \\
\hline \multicolumn{4}{|l|}{ NP3 } \\
\hline Multi-trait model & 3783.94 & 0.0 & $\approx 1.00$ \\
\hline Repeatability model & 3821.10 & 37.20 & $\approx 0.00$ \\
\hline \multicolumn{4}{|l|}{ LW0 } \\
\hline Multi-trait model & 4593.49 & 0.00 & $\approx 1.00$ \\
\hline Repeatability model & 6318.65 & 1725.16 & $\approx 0.00$ \\
\hline \multicolumn{4}{|l|}{ LW3 } \\
\hline Multi-trait model & 7989.21 & 6772.83 & $\approx 0.00$ \\
\hline Repeatability model & 1216.38 & 0.00 & $\approx 1.00$ \\
\hline \multicolumn{4}{|l|}{ MW0 } \\
\hline Multi-trait model & -2533.48 & 0.00 & $\approx 1.00$ \\
\hline Repeatability model & -2448.47 & 85.01 & $\approx 0.00$ \\
\hline \multicolumn{4}{|l|}{ MW3 } \\
\hline Multi-trait model & 1385.01 & 0.00 & $\approx 1.00$ \\
\hline Repeatability model & 1443.13 & 58.12 & $\approx 0.00$ \\
\hline
\end{tabular}

$\mathrm{NBA}=$ number of piglets born alive; NP3 $=$ number of piglets alive at 3 week of age; LW0 $=$ litter weight at birth; LW3 = litter weight at 3 week of age; MW0 = mean piglet weight at birth and MW3 = mean piglet weight at 3 week of age. 


\section{DISCUSSION}

A controversial point regarding the analysis of litter traits in pigs is whether one should consider the measurements from different farrowings as distinct traits or as repeated measures of the same trait. Thus, we analyzed litter traits of Landrace pig breed using the multi-trait and repeatability models.

Heritability estimates obtained for the traits NBA, NP3, LW3, and MW0 increased from the first to the second farrowing and decreased from the second to the third farrowing. Using the multi-trait model, Roehe \& Kennedy (1995) also reported this pattern for the LW3 trait in Landrace pig breed. According to these authors, this observation may be related to the overestimation of genetic variance in the second farrowing. A study focusing on the multi-trait model for the NBA trait in Large White pigs showed an increasing pattern of heritability up to the third farrowing, which differs from our findings (BARBOSA et al., 2010).

Noguera et al. (2002) found the same systematic increasing trend and this tendency was observed until the sixth farrowing. Likewise we found that MW3 and LW0 showed an increasing pattern of heritability up to the third farrowing. Similar analyses concerning NP3 and MW0 have not been reported yet.

The trait MW0 showed the highest heritability value found for all farrowings, a mean of 0.36. Although Damgaard et al. (2003) did not analyze litter traits' heritability according to the order of farrowing, they reported that MW0 was also the trait with the highest heritability (0.39). Similarly to other studies, the first farrowing presented the lowest heritability in all studied traits
(ROEHE \& KENNEDY, 1995; BARBOSA et al., 2010).

The genetic correlations between NBA, NP3, and LW3 did not present a regular pattern among farrowings. On the other hand, the traits LWO, MW0, and MW3 presented high genetic correlations among different farrowings, albeit not equal to one. According to Barbosa et al. (2010), knowing the magnitude of correlations between farrowings is important to define the best evaluation process for breeding programs. High genetic correlation suggests that these traits are controlled by the same genes or gene combinations, implying in selection for a given trait in the first farrowing results in genetic gains for this trait in subsequent farrowings. The suitability of the repeatability model depends on considering the trait to be the same among the farrowings whereas in the multi-trait model these different measures would be considered different traits (ROEHE \& KENNEDY, 1995).

The additive genetic variance estimated by the multi-trait model for all the traits in the first farrowing were more discrepant and with lower values than those observed in the other farrowings. This difference in the additive genetic variances suggests a trend for expression of additive genetic effects of these traits with the progress of the reproductive life of the sow (HERMESCH et al., 2000; ARANGO et al., 2005). In this context, a lower genetic variance rather than an increase in environmental variance is one of the main cause for the reduced heritabilities in the first parity.

The likelihood probabilities (W) show that the repeatability model is the poorer choice for almost all of the studied traits, except for LW3, because it assumes the same additive genetic and residual variances among the farrowings. This variation may be 
caused by the changes in the genetic basis responsible for the expression of the trait in the different farrowings along the life of the sow (WOLF et al., 2008).

The increase of the heritability as well as the different variance components obtained along the order of farrowings could indicate that distinct genetic bases affect litter traits over the reproductive life of the sow as suggested by Roehe \& Kennedy (1995). Indeed, sows' hormonal and physiological development have been shown to affect litter size throughout the reproductive life of the sow (NOGUERA et al., 2002). These effects may represent the genetic bases accounting for the genetic parameters for the traits analyzed herein along the order of farrowings.

Analyzing the percentage of coincident selected animals in different percentiles of selection, a considerable portion of the animals selected would not be selected depending on the statistical model used. This would probably affect the genetic gain for the analyzed traits. Therefore, for these traits in this population the multi-trait model should be used in genetic evaluation.

To our knowledge, this work is the first research comparing six pig litter traits along three orders of farrowing to predict genetic parameters with the repeatability model and a multi-trait model considering each trait in the different farrowings as different traits. By analyzing so many traits instead of only one or two, we were able to assess that these traits have different genetic parameters. Studying these traits along different orders of farrowing in a multitrait model we found different genetic correlations among them, which suggests they should be treated as different traits. The knowledge of these correlations is an important tool to plan selection strategies in breeding programs.

Although the repeatability model is easier to implement and fit, being a good choice to save money and time, breeders must know whether the correlation between the measures of the traits are closer to one so this model can be implemented without affect genetic progress. Whenever these correlations are different, as were the results obtained in our study, the multi-trait model would be preferable.

In conclusion, the multi-trait model is recommended for genetic evaluation of the traits number of piglets born alive and alive at 3 week of age, litter weight and mean piglet weight at birth and 3 week of age, in different farrowings, as different traits.

\section{ACKNOWLEDGMENTS}

This study was supported by Coordenação de Aperfeiçoamento de Pessoal de Nivel Superior (CAPES), Conselho Nacional de Desenvolvimento Científico e Tecnológico (CNPq), and Fundação de Amparo à Pesquisa do Estado de Minas Gerais (FAPEMIG).

\section{REFERENCES}

AKAIKE, H. A new look at the statistical model identification. IEEE Transactions on Automatic Control, v.19, n.6, p.716-723, 1974.

ARANGO, J.; MISZTAL, I.; TSURUTA, S.; CULBERTSON, M.; HERRING, W. Threshold-linear estimation of genetic parameters for farrowing mortality, litter size, and test performance of Large White sows.

Journal of Animal Science, v.83, n.3, p.499-506, 2005. 
Rev. Bras. Saúde Prod. Anim., Salvador, v.17, n.4, p.666-676 out./dez., 2016 http://www.rbspa.ufba.br ISSN 15199940

BARBOSA, L.; LOPES, P.S.; REGAZZI, A.J.; TORRES, R.D.A.; SANTANA JÚNIOR, M.L.;

VERONEZE, R. Estimation of variance components, genetic parameters and genetic trends for litter size of swines. Revista Brasileira de Zootecnia, v.39, n.10, p.2155-2159, 2010.

BURNHAM, K.P.; ANDERSON, D.R. Multimodel Inference: Understanding AIC and BIC in Model Selection. Sociological Methods \& Research, v.33, p.261-304, 2004.

DAMGAARD, L.H.; RYDHMER, L.; LØVENDAHL, P.; GRANDINSON, K. Genetic parameters for within-litter variation in piglet birth weight and change in within-litter variation during suckling. Journal of Animal Science, v.81, n.3, p.604-610, 2003.

FOXCROFT, G.; PATTERSON, J.; DYCK, M. Improving production efficiency in a competitive industry. In: MANITOBA SWINE SEMINAR. SHARING IDEAS AND INFORMATION FOR EFFICIENT PORK PRODUCTION, 24, Winnipeg, Manitoba. ProceEdINGS... Winnipeg, Manitoba: Manitoba Pork Council, 2010. p.81-98.

HERMESCH, S.; LUXFORD, B.G.; GRASER, H.U. Genetic parameters for lean meat yield, meat quality, reproduction and feed efficiency traits for Australian pigs: 3. Genetic parameters for reproduction traits and genetic correlations with production, carcase and meat quality traits.

Livestock Production Science, v.65, n.3, p.261-270, 2000.

KRUPA, E.; WOLF, J. Simultaneous estimation of genetic parameters for production and litter size traits in Czech Large White and Czech Landrace pigs.
Czech Journal of Animal Science, v.58, n.3, p.429-436, 2013.

LUND, M.S.; PUONTI, M.; RYDHMER, L.; JENSEN, J.

Relationship between litter size and perinatal and pre-weaning survival in pigs. Animal Science-Glasgow, v.74, n.2, p.217-222, 2002.

MEYER, K. WOMBAT: A tool for mixed model analyses in quantitative genetics by restricted maximum likelihood (REML). Journal of Zhejiang University Science B, v.8, n.11, p.815-821, 2007.

NOGUERA, J.; VARONA, L.; BABOT, D.; ESTANY, J. Multivariate analysis of litter size for multiple parities with production traits in pigs: I. . Bayesian variance component estimation. Journal of Animal Science, v.80, n.10, p.2540-2547, 2002.

PILES, M.; GARCIA, M.L.; RAFEL, O.; RAMON, J.; BASELGA, M. Genetics of litter size in three maternal lines of rabbits: repeatability versus multiple-trait models. Journal of Animal Science, v.84, p.2309-2315, 2006.

PUTZ, A. M.; TIEZZI, F.; MALTECCA, C.; GRAY, K. A.; KNAUER, M.T. Variance component estimates for alternative litter size traits in swine. Journal of Animal Science, v. 93, n.11, p.5153-5163, 2015.

ROEHE, R.; KENNEDY, B. Estimation of genetic parameters for litter size in Canadian Yorkshire and Landrace swine with each parity of farrowing treated as a different trait. Journal of Animal Science, v.73, n.10, p.29592970, 1995. 
Rev. Bras. Saúde Prod. Anim., Salvador, v.17, n.4, p.666-676 out./dez., 2016 http://www.rbspa.ufba.br ISSN 15199940

SORENSEN, D.; VERNERSEN, A.;

ANDERSEN, S. Bayesian analysis of response to selection: A case study using litter size in Danish Yorkshire pigs. Genetics, v.156, p.283-295, 2000.

SUGIURA, N. Further analysis of the data by Akaike's Information Criterion and the finite corrections.

Communications in Statistics, Theory and Methods, v.A7, p.13-26, 1978.

WOLF, J.; ŽÁKOVÁ, E.; GROENEVELD, E. Within-litter variation of birth weight in hyperprolific Czech Large White sows and its relation to litter size traits, stillborn piglets and losses until weaning. Livestock Science, v.115, p.195-205, 2008.

Data de recebimento: 25/04/2016

Data de aprovação: 09/06/2016 